\title{
EVALUATION OF THE QUALITY OF LIFE IN CHRONIC OBSTRUCTIVE PULMONARY DISEASE IN OVERWEIGHT PATIENTS
}

DOI: 10.36740/WLek202008115

\author{
Mykola M. Ostrovskyy, Nadiia V. Korzh \\ IVANO-FRANKIVSK NATIONAL MEDICAL UNIVERSITY, IVANO-FRANKIVSK, UKRAINE
}

\begin{abstract}
The aim: To evaluate the effect of overweight on the quality of life of chronic obstructive pulmonary disease (COPD) patients GOLD III.

Materials and methods: 65 patients with chronic obstructive pulmonary disease (COPD GOLD III) were examined in different phases of pathological process. The pulmonary function (PF) test was performed by means of "SPIROKOM" device (Ukraine). The degree of overweight was determined by calculating the body mass index (BMI) using the formula $\mathrm{I}=\mathrm{m} / \mathrm{h}^{2}\left(\mathrm{~m}\right.$ - body mass in kilograms, $\mathrm{h}$ - height, square of the height in meters $\left(\mathrm{kg} / \mathrm{m}^{2}\right)$. Patients' quality of life was evaluated with the help of standardized St.George's Respiratory Questionnaire (SGRQ).

Results: The study revealed changes in the PF indices and the decrease in quality of life in overweight patients, especially in case of destabilization of the pathological process. Conclusions: The obtained results show that overweight is the underlying condition for more severe course of the pathology and requires further study of its impact on the health and quality of life of patients in order to improve the effectiveness of treatment.
\end{abstract}

KEY WORDS: chronic obstructive pulmonary disease, overweight, quality of life

\section{INTRODUCTION}

A number of epidemiological studies conducted over many years show that respiratory diseases account for a considerable percentage of cases among other pathologies, and chronic obstructive pulmonary disease (COPD) remains one of the most significant chronic pathological conditions and medical and social problem in modern society, as it is widespread in both advanced and developing countries. Thus, in 1990 COPD was ranked 6 th among all the causes of death and in 20012.7 million people died of this disease that accounted for $5 \%$ of all lethal cases all over the world. [1-3]. According to the data of the World Health Organization (WHO), COPD affects 210 million people and its incidence is expected to increase by $30 \%$ in ten years (WHO, 2014). Furthermore, the key factor, which determinates the urgency of COPD issue, is its high treatment costs for both the health care system and society as a whole. The statistics of Global Initiative (GOLD, 20172018) shows that EU annual direct COPD costs reach 38.6 billion euros. Total COPD costs are three times higher than those for bronchial asthma $[4,5,11]$.

This pathology is characterized by evident systemic symptoms and high comorbidity. The combination of COPD with any other pathology remains a risk factor for frequent exacerbations, each of which continuously aggravates the course of the disease and approaches the irreversible outcome [6-8]. It has been established that after the second severe exacerbation of this pathology the quality of patient's life is significantly impaired, and the mortality rate is 1.9 times higher as compared to the first one. Frequent exacerbations dramatically increase medical expenses and negatively affect the quality of patient's life, which is explained by the escalation of COPD regimens, especially in the case of hospitalization. $[9,10]$.

Currently COPD is considered as a progressive impairment of respiratory function (RF), mainly caused by pollutants and associated with the inflammatory process leading to the weakening of pulmonary function, which progresses with the disease severity and is accompanied by the development of a number of serious, and often, life-threatening complications (Feshchenko Yu.I., 2018). Recently, much attention has been paid to the study of the possible role of extrapulmonary factors which are of great clinical and prognostic value and are associated with the escalation of COPD exacerbation risks [12-15]. Special attention is drawn to the study of ventilatory disorders in COPD patients with overweight, which is one of the key problems of the $21^{\text {st }}$ century and is one of the non-communicable diseases leading to increased morbidity and mortality, incapacitation and disability. (L.M.Niu, 2012; N.Hizawa, 2013; K.F. Rabe, 2014). Excessive weight is one of the factors influencing the development and rapid progression of respiratory pathology that may be proved by the fact that weight loss leads to the decrease in the severity of clinical manifestations of this pathology. The analysis and systematic review carried out in 28 countries of the world showed that the incidence of the pathology among adult population is approximately $10 \%$ (Yu.I. Feshchenko et al., 2017). According to the WHO normal body mass index (BMI) is considered to be between $18.5-24.9 \mathrm{~kg} / \mathrm{m}^{2}$, while the BMI of between $25.0-29.9 \mathrm{~kg} /$ 
$\mathrm{m}^{2}$ is considered as overweight. The possible mechanisms underlying the comorbidity connected with excessive weight and COPD progression may be associated with smoking, decreased physical activity, use of systemic corticosteroids, oxidative stress, hypoxia and inflammation (M. C. McCormack, 2015).

Overweight has a pronounced negative impact on the quality of life (QOL) of patients, and its investigation is an integral part of modern medical science. This index characterizes physical, psychological and emotional functioning of the person [16-18]. The most significant decrease in quality of life is observed in case of chronic pathology, COPD in particular, which requires long-term management and significantly changes the person's lifestyle, resulting in significant limitation of functionality [19-22]. According to WHO's recommendations, quality of life is defined as individuals' perception of their position in life of society in relation to their goals, plans, opportunities and expectations. [16,21]. The main criteria for quality of life as defined by the World Health Organization (WHO) are: physical (strength, energy, fatigue, pain, discomfort, sleep, rest); psychological (positive emotions, thinking, learning, concentration, self-esteem, appearance, feelings); the level of independence (daily activities, work capacity, drug dependence and treatment); social relationships (personal relationships, social support, sexual activity); environment (daily life, well-being, safety, accessibility and quality of medical and social care, security, ecology, learning opportunities, information accessibility); spirituality (religion, personal beliefs) [5,21,22]. Patients' quality of life is evaluated with the help of standardized questionnaires, including the St. George's Respiratory Questionnaire (SGRQ), which studies health disorders of patients with bronchial asthma, COPD, bronchiectatic disease, kyphoscoliosis, sarcoidosis, and has undergone the validation procedures in different languages and is used in everyday practice in many countries [22] allowing to assess the level of adaptive capacity of the patient.

\section{THE AIM}

The aim of this study was to evaluate the effect of overweight on the quality of life of COPD patients GOLD III.

\section{MATERIALS AND METHODS}

65 patients with chronic obstructive pulmonary disease (COPD GOLD III) were examined in different phases of pathological process. Diagnosing and complex therapy were carried out according to the schemes, provided by the GOLD 2018 materials and the order of the Ministry of Health of Ukraine №555 from June 27, 2013 "Unified clinical protocol for primary, secondary and tertiary medical care and rehabilitation for COPD patients». The pulmonary function $(\mathrm{PF})$ test was performed by means of "SPIROKOM" device (Ukraine). The degree of overweight was determined by calculating the body mass index (BMI) using the formula $\mathrm{I}=\mathrm{m} / \mathrm{h}^{2}(\mathrm{~m}-$ body mass in kilograms, $\mathrm{h}$ - height, square of the height in meters $\left(\mathrm{kg} / \mathrm{m}^{2}\right)$. Patients quality of life was evaluated with the help of standardized St.George's Respiratory Questionnaire (SGRQ). All the patients were male and the average age index was (59.3 \pm 3.2 ) years.

\section{RESULTS AND DISCUSSION}

Overweight was diagnosed in $36.9 \%$ of the examined patients (BMI $\left.-25.0-29.9 \mathrm{~kg} / \mathrm{m}^{2}\right)$. All the patients were diagnosed with marked airway obstruction confirmed by means of spirography. Moreover, the FEV1 index in obese patients made up (45.63 \pm 2.07$) \%$ that is $7.2 \%$ lower than the same index in patients with normal body weight. Thus, changes in the PF indices were more evident in patients with destabilization of the pathological process. The QOL analysis with St. George's Respiratory Questionnaire (SGRQ) involved 4 generalized scales as assessment parameters: "Symptoms" - patient's subjective assessment of the severity of COPD clinical signs; "Physical activity" - patient's subjective assessment of the degree of limitation of his physical activity associated with the disease; «Psychological impact» - patient's subjective assessment of the severity of psychological and social problems caused by the disease. The total count of scores "Total" - the influence of the disease on the general state of health, has also been calculated. The score of 100 points corresponded to the worst possible health condition, 0 points - to the best one (Jones P.W., Forde Y., 2008).

The review showed the development of more evident disorders in patients with overweight. Thus, the QOL parameters on the scales of «Physical activity» $(52.19 \pm 2.93$ points), «Psychological influence» (44.25 \pm 2.95 points), and final assessment $(48.82 \pm 2.64$ points) were decreased in overweight patients as compared to patients with normal body weight, where these scores were («Physical activity» - (34.11 \pm 3.28 points), «Psychological impact» - (31.04 \pm 2.84 points $)$, and the final score $-(35.35 \pm 2.69$ points $)$, $(\mathrm{p}<0.05)$ as evaluated by the same scale "Symptoms of the disease". These changes were characterized by the reduction of physical activity of patients: difficulties in performing essential daily physical activities, namely cleaning-up, lifting and carrying of small and simple objects, difficulties with walking up and down the stairs, difficulties with performing slopes and squats, which were associated with overweight. At the same time, patients noted an increase in the time required to conduct a certain type of training, and dissatisfaction with the result. The analysis of medical records revealed that the pathology exacerbations were twice as frequent within a year in overweight patients as compared to the patients with normal body weight.

\section{CONCLUSIONS}

The course of COPD GOLD III in overweight patients is accompanied by more frequent development of destabilization of the pathology, more prominent reduction of FEV1 in this phase and a decrease in the quality of life parameters 
on the scale of physical activity by 9 points, as compared with COPD GOLD III patients with normal body weight. These changes should be taken into account while assessing the effectiveness of treatment and developing individual rehabilitation programs.

\section{REFERENCES}

1. Hashynova K.Yu.Vplyv komorbidnoi patolohii na chastotu hospitalizatsii pry zahostrenni na khronichne obstruktyvne zakhvoriuvannia lehen. Halytskyi Likarskyi Visnyk. 2014;3:15-18. (In Ukrainian).

2. Mostovyi Yu.M. Khronichne obstruktyvne zakhvoriuvannia lehen. Kliuchovi pytannia (Chronic obstructive pulmonary disease. Key issues). Ukr.Med.Chasopys. 2016;4:63-66. (In Ukrainian).

3. Agusti A., Thomas A. Neff lecture. Chronic obstructive pulmonary desease. Proc. Am. Thorac. Soc. 2006;3(6):478-481.

4. Feshchenko Yu.I., Chaikovskyi Yu.B., Ostrovskyi M.M., et al. Khronichne obstruktyvne zakhvoriuvannia lehen. Novi vidtinky problemy (Chronic obstructive pulmonary disease. New shades of the problem). IvanoFrankivsk. 2016:40p. (In Ukrainian).

5. Jones P.W., Quirk F.H., Baveystock C.M. The St George's Respiratory Questionnaire. Respir Med. 1991;85 Suppl B:25-31.

6. Order of the Ministry of Health of Ukraine №555 from June 27, 2013. Pro zatverdzhennia ta vprovadzhennia medyko-tekhnolohichnykh dokumentiv zi standartyzatsii medychnoi dopomohy pry khronichnomu obstruktyvnomu zakhvoriuvanni lehen. Kyiv, 2013:146p. (In Ukrainian).

7. Ostrovskyi M.M., Varunkiv 0.I., Malofii L.S., et al. Novi mozhlyvosti vplyvu na bronkhoobstruktyvnyi syndrom pry zahostrenniakh khronichnoho obstruktyvnoho zakhvoriuvannia lehen. Halytskyi Likarskyi Visnyk. 2011;18(14):116-121. (In Ukrainian).

8. Ostrovskyi M.M., Stovban M.P. Fenotyp KhOZL iz chastymy zahostrenniamy: vplyv na shvydkist prohresuvannia khvoroby i prohnoz dlia patsiienta. Zdorovia Ukrainy. 2013;3(23):29-30. (In Ukrainian).

9. Celli B.R., MacNeeW. ATS/ERSTask Force. Standards for the diagnosis and treatment of patients with COPD: a summary of the ATS/ERS position paper. Eur. Respir. J. 2004;23:932-946.

10. Chatila W.M., Thomashow B.M., Minai O.A. Comorbidities in chronic obstructive pulmonary disease. Proc. Am. Thorac. Soc. 2008;5:549-555.

11. Global Initiative for Chronic Obstructive Lung Disease. Global Strategy for the Diagnosis, Management, and Prevention of Chronic Obstructive Pulmonary Disease. NHLBI/WHO workshop report . National Heart, Lung, and Blood Institute. 2018. doi:http: // www.goldcopd.com

12. Bychkova S.A. Kliniko-funktsionalni osoblyvosti perebihu khronichnoho obstruktyvnoho zakhvoriuvannia lehen, poiednanoho z metabolichnym syndromom. Likarska Sprava. 2014;7-8:54-59. (In Ukrainian).

13. Halamba A.A., Tovt-Korshynska M.I. Zastosuvannia pokaznykiv yakosti zhyttia u khvorykh na bronkhialnu astmu v praktytsi simeinoho likaria. Simeina medytsyna. 2011;1:30-33. (In Ukrainian).

14. Hashynova K.Yu. Systemni proiavy ta komorbidnist u ambulatornykh patsientiv z KhOZL. Ukr.Pulmonol.Zhurnal. 2013;2:41-45. (In Ukrainian).

15. Mostovoi Yu.M., Rasputina L.V., Dovhan A.0. et al. Problema komorbidnykh staniv u Natsionalnii uhodi z diahnostyky ta likuvannia khronichnoho obstruktyvnoho zakhvoriuvannia lehen iz pozytsii vlasnoho dosvidu. Obhovorennia Nakazu №555. Bukovynskyi Medychnyi Visnyk. 2014;18(3):221-226. (In Ukrainian).
16. Feshchenko Yu.I., Yashyna L.A., Opimakh S.H. Vplyv porushen hazoobminu na parametry yakosti zhyttia u patsiientiv iz khronichnym obstruktyvnym zakhvoriuvanniam lehen. Ukr.Med.Chasopys. 2014;1(99):140-144. (In Ukrainian).

17. Barnes P.J., Celli B.R. Systemic manifestations and comorbidities of COPD. Eur. Respir. J. 2009;33:1165-1185.

18. Vanfleteren L.E. et al. Body mass index and chronic airflow limitation in a worldwide population-based study. Chron.Respir.Dis. 2016;13(2):90-101.

19. Calverley P.M.A. The GOLD classification has advanced understanding of COPD. Am. J. Respir. Crit. Care Med. 2004;170:211-212.

20. Han M.K., Agusti A., Calverley P.M. et al. COPD phenotypes: The future of COPD. Am. J. Respir. Crit. Care Med. 2010;182:598-604.

21. National Institutes of Health, National Heart, Lung, and Blood Institute. Clinical Guidelines on the Identification, Evaluation,and Treatment of Overweight and Obesity in Adults-the evidence report. Obes. Res. 1998; 6(2);51-209.

22. Vandevijvere S., Chow C.C., Hall K.D, Umalia E. et al. Increased food energy supply as a major driver of the obesity epidemic: a global analysis. Bull World Health Organ. 2015;93:446-456.

This article is prepared in the course of scientific work for the PhD degree (Candidate of Sciences) on the Department of phthisiology and pulmonology with the course of occupational diseases, Ivano-Frankivsk National Medical University.

\section{ORCID and contributionship:}

Mykola M. Ostrovskyy: 0000-0002-3922-0583 A,D,E,F

Nadiia V. Korzh: 0000-0002-4262-8600 A,B,C,D

\section{Conflict of interest:}

The Authors declare no conflict of interest.

\section{CORRESPONDING AUTHOR Nadiia V. Korzh \\ Ivano-Frankivsk National Medical University \\ 2 Halytska St., 76018 Ivano-Frankivsk, Ukraine \\ tel: +38(0342)533295, \\ e-mail: nadiyakorzh@gmail.com}

Received: 23.09 .2019

Accepted: 30.06 .2020
A - Work concept and design, B - Data collection and analysis, $\mathbf{C}$ - Responsibility for statistical analysis, $\mathbf{D}$-Writing the article, $\mathbf{E}$-Critical review, $\mathbf{F}$ - Final approval of the article 